\title{
Pengaruh Pemberian Kawa Daun Gambir terhadap Kadar Malondialdehid Jaringan Hati Mencit Diabetes yang Diinduksi Aloksan
}

\author{
Fachrurrazi Al Ansori', Nur Indrawaty Lipoeto², Julizar ${ }^{3}$ \\ ${ }^{1}$ Profesi Dokter Fakultas Kedokteran Universitas Andalas, Padang \\ ${ }^{2}$ Bagian Gizi Fakultas Kedokteran Universitas Andalas, Padang \\ ${ }^{3}$ Bagian Fisika Fakultas Kedokteran Universitas Andalas, Padang
}

A B S T R A C T

Latar Belakang. Kawa daun gambir (Uncaria gambir Roxb) merupakan minuman yang terbuat dari daun gambir yang dikeringkan dan diseduh seperti membuat teh yang mengandung senyawa epicathecin, epicathecin-3-gallate, epigalloctahechin-3-gallate, dan epigallocathechin yang berpotensi menurukan kadar MDA jaringan hati.

Objektif. Penelitian ini bertujuan untuk mengetahui pengaruh pemberian kawa daun gambir (Uncaria gambir Roxb) terhadap kadar MDA jaringan hati mencit (Mus musculus) diabetes yang diinduksi aloksan.

Metode. Penelitian ini merupakan true experimental dengan post-test only control group design. Sebanyak 30 ekor mencit dibagi menjadi lima kelompok yaitu $\mathrm{K}-, \mathrm{K}+, \mathrm{P} 1, \mathrm{P} 2, \mathrm{P} 3$. Kelompok K+, P1, P2, dan P3 diinduksi aloksan. Kemudian dilanjutkan dengan pemberian kawa daun gambir dosis 1 $\mathrm{gr} / 100 \mathrm{ml}, 2 \mathrm{gr} / 100 \mathrm{ml}$, dan $4 \mathrm{gr} / 100 \mathrm{ml}$ untuk P1, P2, dan P3 selama 14 hari. Rerata kadar MDA jaringan hati diperiksa dengan metode thiobarbituric acid reactive substances (TBARS). Analisis data menggunakan One-way ANOVA dan Post Hoc Least Significant Differences (LSD).

Hasil. Induksi aloksan dapat meningkatkan kadar MDA jaringan hati kelompok kontrol positif, dan kelompok perlakuan dibanding kontrol negatif. Rerata kadar MDA jaringan hati pada kontrol negatif adalah $8,34 \mathrm{nmol} / \mathrm{ml}$, kontrol positif 12,71 $\mathrm{nmol} / \mathrm{ml}$, perlakuan satu $10,64 \mathrm{nmol} / \mathrm{ml}$, perlakuan dua 8,35 $\mathrm{nmol} / \mathrm{ml}$, perlakuan tiga $8,46 \mathrm{nmol} / \mathrm{ml}$. Terdapat perbedaan yang signifikan pengaruh pemberian kawa daun gambir pada perlakuan 1 , perlakuan 2 , dan perlakuan 3 terhadap kontrol positif, $p=0,000(p<0,05)$. Tidak terdapat perbedaan perlakuan 2 dan perlakuan 3 terhadap kontrol negatif, $p=0,986$. Kesimpulan. Kawa daun gambir dapat menurunkan kadar MDA jaringan hati.

Kata kunci: aloksan, gambir, kawa daun, malondialdehid jaringan hati

Background. Kawa daun gambir (Uncaria gambir Roxb.) is a drink brewed from dried gambir leaves that contains epicathecin, epicathecin-3-gallate, epigalloctahechin-3-gallate, and epigallocathechin which are useful in decreasing MDA liver tissue level.

Objective. This study aimed to determine the effect of kawa daun gambir (Uncaria gambir Roxb.) on MDA liver tissue level of diabetic mice (Mus musculus) induced by alloxan.

Methods. This study was experimental study with post-test only control group design. The study was performed on 30 mice that were divided into 5 groups. The negative control group $(K-)$, positive control group $(K+)$, and 3 treatment groups (P1, P2, P3) were induced by alloxan. The treatment group received $1 \mathrm{gr} / 100 \mathrm{~mL}, 2 \mathrm{gr} / 100 \mathrm{~mL}$, and $4 \mathrm{gr} / 100 \mathrm{~mL}$ for 14 days of kawa daun gambir. The MDA liver tissue level were examined by thiobarbituric acid reactive substances (TBARS) method. One-way ANOVA and Post Hoc Least Significant Differences (LSD) test were used to analyze the data.

Results. Alloxan induction could increase MDA levels of liver tissue in the positive control group, and the treatment group compared to the negative control group. The average level of MDA liver tissue for negative control group (K-) was 8,34 $\mathrm{nmol} / \mathrm{mL}$, the positive control group was $12,71 \mathrm{nmol} / \mathrm{mL}, P 1$ was 10,64 $\mathrm{nmol} / \mathrm{mL}$, P2 was 8,35 nmol/ $\mathrm{mL}$, and P3 was 8,46 $\mathrm{nmol} / \mathrm{mL}$. There was a significant difference in MDA tissue level among the groups after receiving kawa daun gambir with $p$ value $=0,000(p<0,05)$. There was no difference found in treatment 2 and treatment 3 to the negative control group, $p=$ 0,986 .

Conclusion. Kawa daun gambir can decrease MDA liver tissue level.

Keywords: alloxan, gambir, kawa daun, malondialdehid, liver tissue

Apa yang sudah diketahui tentang topik ini?

Kawa daun gambir (Uncaria gambir Roxb) merupakan minuman yang terbuat dari daun gambir yang dikeringkan dan diseduh seperti membuat teh yang mengandung senyawa epicathecin, epicathecin-3-galleate, epigallocathecin-3-galleate dan epigallocatechin yang berpotensi menurukan kadar MDA jaringan hati.

Apa yang ditambahkan pada studi ini?

Kawa daun gambir dapat menurunkan kadar MDA jaringan hati.

\section{CORRESPONDING AUTHOR}

Phone: +6282284372646

E-mail: alansori02@gmail.com

\section{ARTICLE INFORMATION}

Received: March 10 ${ }^{\text {th }}, 2020$

Revised: March $16^{\text {th }}, 2020$

Available online: March $20^{\text {th }}, 2020$ 


\section{Pendahuluan}

Urbanisasi dan modernisasi menyebabkan perubahan gaya hidup, hal ini memicu timbulnya berbagai jenis penyakit degeneratif. Penyakit degeneratif muncul akibat kerusakan sel, jaringan lemak, protein, sistem kekebalan sehingga menurunkan fungsi sel-sel tubuh. Salah satu penyakit degeneratif adalah diabetes melitus. ${ }^{1}$

Diabetes Melitus (DM) merupakan penyakit metabolik kronis yang ditandai dengan peningkatan kadar gula darah akibat kurangnya sekresi hormon insulin, respon tubuh yang tidak adekuat terhadap insulin, atau gabungan keduanya. 2,3 DM dapat diklasifikasikan menjadi 4 tipe yaitu DM tipe 1, DM tipe 2, DM Gestasional dan DM tipe lain.

DM tipe 1 ditandai dengan penurunan sekresi insulin karena kerusakan autoimun sel $\beta$ pankreas sehingga dibutuhkan tambahan insulin dari luar tubuh, sedangkan DM tipe 2 ditandai dengan adanya resistensi insulin pada sel-sel tubuh atau sekresi insulin oleh sel $\beta$ pankreas tidak adekuat. DM Gestasional terjadi pada masa kehamilan karena terdapat intoleransi glukosa akibat hormon estrogen yang dieksresikan plasenta sehingga menghambat kerja insulin., 4

Jumlah penderita DM mengalami peningkatan setiap tahunnya. Berdasarkan data WHO tahun 2017, penderita DM usia 18 tahun ke atas mengalami peningkatan dari $4,7 \%$ dengan total penderita 108 juta pada tahun 1980 menjadi 8,5\% dengan total 422 juta penderita pada tahun $2014 .{ }^{3}$ Berdasarkan data International Diabetes Federation tahun 2015, lebih kurang 414,7 juta penduduk dunia dengan usia 20 - 79 tahun menderita DM. Indonesia menempati peringkat ke-7 dari 10 negara penderita DM tertinggi di dunia setelah Cina, India, Amerika Serikat, Brazil, Rusia dan Meksiko dengan total 10 juta kasus pada tahun 2015. ${ }^{6}$ Diperkirakan Indonesia akan berada di urutan ke-6 dari 10 negara penderita DM terbanyak pada tahun 2040 dengan jumlah 16,2 juta penderita DM. ${ }^{2}$

Menurut Riskesdas tahun 2013, prevalensi DM di Indonesia adalah 1,5\% dan prevalensi penyakit DM di Provinsi Sumatera Barat adalah 1,3\%. Kota Bukittingi $(2,6 \%)$, Kota Pariaman $(2,6 \%)$, Kota Sawah Lunto $(2,2 \%)$, Pesisir Selatan $(1,9 \%)$ dan Pasaman Barat merupakan Kabupaten/Kota yang menempati prevalensi DM tertinggi di Provinsi Sumatera Barat. ${ }^{7}$
Kurangnya aktivitas fisik dan kelebihan nutrisi yang mengarah pada obesitas merupakan penyebab umum tingginya prevalensi DM sehingga menyebabkan kadar glukosa dan free fatty acid (FFA) dalam darah meningkat.8,9 Kedua senyawa tersebut dapat menimbulkan stres oksidatif. Stres oksidatif terjadi apabila jumlah oksidan lebih banyak dibandingkan jumlah antioksidan di dalam tubuh. Salah satu oksidan yang diproduksi tubuh sebagai konsekuensi dari metabolisme fisiologis adalah reactive oxygen species (ROS).8,10 Meningkatnya jumlah ROS yang diproduksi dapat memicu terjadinya resistensi insulin, khususnya di organ hati. ${ }^{8}$

Hati bertanggung jawab pada proses glukoneogenesis dan glikogenesis. Saat resistensi insulin terjadi, maka kedua proses tersebut terganggu dan menyebabkan hiperglikemia. Hiperglikemia memicu kembali terbentuknya ROS.11,12 Lipid merupakan salah satu target utama ROS. Ketika resistensi insulin hepatik terjadi, jumlah lipid yang terakumulasi di sel hepatosit meningkat. Peningkatan lipid hepatoseluler yang mencapai $\pm 5,5 \%$ disebut nonalcoholic fatty liver (NAFL) yang merupakan manifestasi DM. ${ }^{12}$ Prevalensi pasien diabetes yang menderita NAFL adalah $10-75 \%$, di Amerika Serikat diperkirakan bahwa 36,9\% menderita NAFL. Indonesia sendiri memiliki prevalensi NAFL mencapai 30\% dengan faktor resiko tertinggi diabates dan obesitas. ${ }^{13,14}$

Reactive oxygen species (ROS) akan mengoksidasi asam lemak tak jenuh dan dapat merusak membran sel serta membentuk suatu produk akhir peroksidasi lipid berupa malondialdehid (MDA). Malondialdehid dapat digunakan sebagai biomarker stres oksidatif. ${ }^{15}$ Peningkatan kadar MDA dapat dikurangi dengan adanya antioksidan. Pada penderita DM, jumlah antioksidan mengalami penurunan, sehingga dibutuhkan tambahan antioksidan dari luar tubuh. ${ }^{16}$ Salah satu sumber antioksidan dari luar adalah kawa daun Gambir. ${ }^{17}$

Gambir (Uncaria gambir Roxb) mengandung antioksidan yang sangat tinggi yang didapatkan dari daun dan ranting tumbuhan gambir. Antioksidan yang terkandung pada daun gambir berupa alkaloid dan senyawa fenolik yang termasuk golongan flavonoid yang memiliki aktivitas antioksidan berupa katekin membuat gambir mempunyai banyak manfaat untuk kesehatan.17,18 Edward melaporkan gambir 
berpotensi sebagai hepatoprotektor dengan menurunkan reaksi oksidasi lipid. ${ }^{19}$ Tanaman gambir banyak terdapat di wilayah Sumatera Barat dan Riau sehingga dua wilayah ini menjadi daerah pasaran ekspor dari Indonesia. 18

Kawa daun adalah minuman khas dari Sumatera Barat dan telah merakyat di kalangan masyarakat Minangkabau yang terbuat dari daun kopi yang dikeringkan. ${ }^{20}$ Kawa daun gambir adalah minuman yang terbuat dari daun gambir yang dikeringkan dan diseduh seperti membuat teh. ${ }^{17}$ Penelitian mengenai potensi kawa daun gambir (Uncaria gambir Roxb) sebagai antioksidan yang dilakukan oleh Muhammad A'raaf dkk terhadap mencit putih (Mus musculus) yang diinduksi aloksan mampu menurunkan kadar glukosa darah sebanyak 68\% dengan dosis kawa daun gambir $2 \mathrm{gr} / 100 \mathrm{ml}$ selama 14 hari. ${ }^{17}$

Gambir berperan sebagai antioksidan dan hepatoprotektor, penelitian Fahrudin dkk membuktikan gambir dapat menurunkan enzim hati dalam darah, menurunkan kadar MDA hati dan mampu memperbaiki kondisi fibrosis dan perlemakan hati pada tikus (Rattus norvegicus L.) yang diinduksi CCl4 dengan dosis efektif 26 mg/200 gBB yang diberikan. ${ }^{21}$ Penelitian juga membuktikan peran gambir sebagai antioksidan dalam bentuk isolat katekin mampu menurunkan kadar kolesterol total dan triasilgliserol pada tikus dengan dosis $20 \mathrm{mg} / \mathrm{kgBB}$ yang diberikan selama 14 hari. ${ }^{22,23}$

Berdasarkan latar belakang diatas, penelitian ini dilakukan dengan tujuan untuk mengetahui efektivitas pemberian kawa daun gambir (Uncaria gambir Roxb) dalam menurunkan kadar MDA pada jaringan hati mencit (Mus musculus) diabetes yang diinduksi aloksan sehingga dapat memberikan informasi ilmiah mengenai efek antioksidan kawa daun gambir sebagai antioksidan tambahan dari luar tubuh untuk mengatasi komplikasi DM khususnya NAFL.

\section{Metode}

Jenis penelitian ini adalah penelitian true experimental dengan pendekatan post-test only control group design yang menggunakan hewan coba sebagai objek penelitian. Kelompok penelitian ini terdiri atas kontrol negatif, kontrol positif, kelompok perlakuan 1, kelompok perlakuan 2, dan kelompok perlakuan 3.
Populasi penelitian ini adalah mencit putih (Mus musculus) yang berumur 8-12 minggu, dengan berat badan berkisar 25-35 gram. Dalam penelitian ini didapatkan besar sampel tiap perlakuan minimal enam ekor mencit, sehingga jumlah total mencit yang dibutuhkan sebanyak 30 ekor mencit.

Kontrol negatif merupakan kelompok normal yang tidak diinduksi aloksan maupun diberikan kawa daun gambir. Kontrol negatif merupakan kelompok yang diinduksi aloksan tanpa diberikan kawa daun gambir. Perlakuan 1, 2, dan 3 merupakan kelompok yang diinduksi aloksan dan diberikan kawa daun gambir masing-masing 1 $\mathrm{gr} / 100 \mathrm{ml}, 2 \mathrm{gr} / 100 \mathrm{ml}$, dan $4 \mathrm{gr} / 100 \mathrm{ml}$ selama 14 hari.

Setelah diinduksi aloksan, 3 hari berikutnya semua kelompok akan diukur kadar glukosa darah. Mencit diabetes didapatkan kadar glukosa darah $>200 \mathrm{mg} / \mathrm{dl}$. Perlakuan pemberian kawa daun gambir diberikan selama 14 hari. Pada hari ke-15, mencit dibedah untuk pengambilan organ hati dilanjutkan dengan pengukuran MDA jaringan hati dengan metode TBARS.

Hasil

Penelitian ini bertujuan untuk mengetahui pengaruh pemberian kawa daun gambir (Uncaria gambir Roxb) terhadap kadar MDA jaringan hati mencit diabetes yang diinduksi aloksan. Hewan percobaan adalah 30 ekor mencit berumur 8-12 minggu dengan berat badan 25-35 gram yang dibagi dalam 5 kelompok, yaitu kelompok kontrol negatif (K-), kelompok kontrol positif $(\mathrm{K}+)$, kelompok perlakuan satu (P1), kelompok perlakuan dua (P2), dan kelompok perlakuan tiga (P3). Ketika dilakukan penelitian terdapat 5 ekor hewan coba yang mati yaitu, pada dosis $1 \mathrm{gr} / 100$ $\mathrm{ml}, 2 \mathrm{gr} / 100 \mathrm{ml}, 4 \mathrm{gr} / 100 \mathrm{ml}$, kontrol negatif, dan kontrol positif. Kematian mencit tersebut tidak mempengaruhi hasil penelitian karena pada penelitian ini menggunakan antisipasi drop out.

Penelitian ini dilakukan di Laboratorium Farmasi Fakultas Farmasi Universitas Andalas, Laboratorium Biomedik Fakultas Kedokteran Universitas Andalas, dan Laboratorium Biokimia Fakultas Kedokteran Universitas Andalas.

Tabel 1. Rerata Kadar MDA Jaringan Hati Mencit setelah Pemberian Kawa Daun Gambir

Kelompok Rerata kadar MDA jaringan hati $(\mathrm{nmol} / \mathrm{ml}) \pm \mathrm{SD}$ 


\begin{tabular}{cc}
\hline $\mathrm{K}-$ & $8,34 \pm 0,19$ \\
$\mathrm{~K}+$ & $12,71 \pm 1,00$ \\
$\mathrm{P} 1$ & $10,64 \pm 1,66$ \\
$\mathrm{P} 2$ & $8,35 \pm 0,94$ \\
$\mathrm{P} 3$ & $8,46 \pm 0,99$ \\
\hline
\end{tabular}

Tabel 1. menunjukkan rerata kadar MDA jaringan hati antar kelompok setelah pemberian kawa daun gambir selama 14 hari. Rerata kadar MDA jaringan hati mencit yang hanya diinduk aloksan (K+) lebih tinggi yaitu $12,71 \mathrm{nmol} / \mathrm{ml}$ dibandingkan dengan K-, P1, P2, dan P3. Kelompok mencit yang hanya diberikan pakan standar sebagai kontrol negatif (K-) memiliki rerata kadar MDA jaringan hati lebih rendah yaitu 8,34 $\mathrm{nmol} / \mathrm{ml}$ dibandingkan $\mathrm{K}+, \mathrm{P} 1, \mathrm{P} 2$, dan P3. Mencit yang diinduksi aloksan dan pemberian kawa daun gambir dosis $1 \mathrm{gr} / 100 \mathrm{ml}, 2 \mathrm{gr} / 100 \mathrm{ml}$ dan $4 \mathrm{gr} / 100 \mathrm{ml}$ mengalami penurunan kadar MDA jaringan hati mencit yaitu $10,64 \mathrm{nmol} / \mathrm{ml}$, $8,35 \mathrm{nmol} / \mathrm{ml}$ dan $8,46 \mathrm{nmol} / \mathrm{ml}$ dibanding kelompok kontrol positif.

Tabel 2. Signifikansi antar Kelompok Hasil Analisis Least Significant Differences (LSD) untuk Kadar MDA Jaringan Hati

\begin{tabular}{cccccc}
\hline Kelompok & K- & K+ & P1 & P2 & P3 \\
\hline K- & - & 0,000 & 0,005 & 0,889 & 0,986 \\
K+ & 0,000 & - & 0,007 & 0,000 & 0,000 \\
P1 & 0,005 & 0,007 & - & 0,004 & 0,005 \\
P2 & 0,889 & 0,000 & 0,004 & - & 0,875 \\
P3 & 0,986 & 0,000 & 0,005 & 0,875 & - \\
\hline
\end{tabular}

Berdasarkan tabel 2 menunjukkan perbedaan yang signifikan didapatkan pada kelompok kontrol positif dengan kontrol negatif dengan nilai $\mathrm{p}=0,000$. Perbedaan yang signifikan juga didapatkan antara kelompok kontrol positif dengan P1, P2, dan P3 dengan nilai $\mathrm{p}<0,05$.

\section{Diskusi}

Berdasarkan tabel 1 kadar rata-rata MDA jaringan hati pada kelompok kontrol negatif adalah 8,34 $\pm 0,19 \mathrm{nmol} / \mathrm{ml}$ dan merupakan kelompok dengan kadar MDA terendah diantara kelompok lainnya. Hal ini menunjukka kadar MDA jaringan hati dalam batas normal karena pada kelompok ini mencit tidak diinduksi aloksan dan tidak diberi perlakuan.

Berdasarkan tabel 1 kadar rata-rata MDA jaringan hati pada kelompok kontrol positif adalah $12,71 \pm 1,00 \mathrm{nmol} / \mathrm{ml}$ dan merupakan kelompok dengan kadar MDA jaringan hati tertinggi diantara kelompok lainnya. Hal ini disebabkan oleh induksi aloksan pada kelompok kontrol positif yang mengakibatkan rusaknya sel beta pankreas mencit, hal ini akan menyebabkan kondisi diabetes pada mencit. Pada diabetes melitus,proses glikogenolisis dan glukoneogenesis dihati menjadi terganggu, sehingga jumlah lipid yang terakumulasi di sel hepatosit meningkat yang menyebabkan komplikasi berupa NAFL. ${ }^{11,12}$ Hal ini menyebabkan peningkatan produksi ROS sehingga terjadi peroksidasi lipid yang mengakibatkan terputusnya rantai asam lemak menjadi senyawa toksik serta merusak membran sel yang akan menyebabkan kerusakan organ dan membentuk produk akhir berupa MDA yang dapat digunakan sebagai biomarker stres oksidatif. ${ }^{15}$

Pada kelompok perlakuan 1 yang diinduksi aloksan dan diberi kawa daun gambir $1 \mathrm{gr} / 100 \mathrm{ml}$ selama 14 hari didapatkan rata-rata kadar MDA jaringan hati 10,64 $\pm 1,66 \mathrm{nmol} / \mathrm{ml}$. Hasil ini lebih rendah dibanding dengan rata-rata kadar MDA jaringan hati mencit kelompok kontrol positif dan terdapat perbedaan yang signifikan. Pada kelompok perlakuan 2 yang diinduksi aloksan dan diberi kawa daun gambir $2 \mathrm{gr} / 100 \mathrm{ml}$ selama 14 hari didapatkan rata-rata kadar MDA jaringan hati $8,35 \pm 0,94 \mathrm{nmol} / \mathrm{ml}$, yang menunjukkan bahwa pemberian kawa daun gambir dosis $2 \mathrm{gr} / 100 \mathrm{ml}$ dapat menurunkan kadar MDA jaringan hati secara signifikan. Pada kelompok perlakuan 3 yang diinduksi aloksan dan diberi kawa daun gambir $4 \mathrm{gr} / 100 \mathrm{ml}$ selama 14 hari didapatkan rata-rata kadar MDA jaringan hati 8,46 $\pm 0,99$ $\mathrm{nmol} / \mathrm{ml}$. Hal ini menunjukkan bahwa pemberian kawa daun gambir dosis $4 \mathrm{gr} / 100 \mathrm{ml}$ juga dapat menurunkan kadar MDA jaringan hati secara signifikan. Diantara ketiga kelompok perlakuan, penurunan kadar MDA jaringan hati yang paling tinggi terdapat pada kelompok perlakuan 2 dengan dosis $2 \mathrm{gr} / 100 \mathrm{ml}$.

Penurunan kadar MDA jaringan hati yang terjadi pada ketiga kelompok perlakuan disebabkan karena kawa daun gambir mengandung senyawa antioksidan terutama senyawa polifenol, yaitu katekin. Katekin pada gambir bermanfaat sebagai antidiabetes sehingga mampu untuk menurunkan kadar glukosa darah pada penderita diabetes. ${ }^{17}$ Katekin juga berperan sebagai antioksidan sehingga katekin mampu mengikat dan menetralkan radikal bebas di dalam tubuh. Katekin merupakan antioksidan larut air yang dapat menurunkan mobilitas radikal bebas 
ke membran lipid bilayer. Flavonoid dapat memasuki lapisan hidrofobik membran kemudian meningkatkan stabilitas membran. Selain itu, flavonoid dapat menurunkan konsentrasi radikal bebas atau meningkatkan kemampuan antioksidan dengan cara memasuki membran lipid bilayer. Oleh karena itu, katekin dapat menurunkan peroksidasi lipid ketika membran fosfolipid terpapar radikal bebas. ${ }^{59}$

Kelompok perlakuan 3 mampu menurunkan kadar MDA jaringan hati lebih baik dibandingkan kelompok perlakuan 1, namun tidak lebih baik dari kelompok perlakuan 2. Variasi penurunan ini menunjukkan bahwa pada dosis $2 \mathrm{gr} / 100 \mathrm{ml}$ merupakan dosis optimal untuk menurunkan kadar MDA jaringan hati. Hasil tersebut didukung oleh penelitian yang dilakukan oleh M. A'raf dkk, bahwa dosis $2 \mathrm{gr} / 100 \mathrm{ml}$ merupakan dosis kawa daun gambir yang optimal untuk menurunkan kadar gula darah. ${ }^{17}$

Hasil penelitian ini sesuai dengan teori hubungan antara suatu konsentrasi zat atau obat dengan respon terapi yang diberikan. Baik pada hewan ataupun manusia, respon yang ditimbulkan oleh suatu zat dalam dosis rendah biasanya akan meningkat berbanding lurus dengan peningkatan dosis. Seiring dengan bertambahnya dosis obat, peningkatan respon tubuh akan berkurang, hingga peningkatan dosis tidak akan menunjukkan peningkatan respon lagi. Gambaran hubungan antara konsentrasi zat atau obat dan efeknya bukan merupakan kurva linear melainkan kurva parabola. ${ }^{67}$

Penelitan ini menunjukkan bahwa dosis 2 gr/100 ml merupakan dosis yang paling optimal karena mampu memberikan respon maksimal yang dihasilkan oleh kawa daun gambir untuk menurunkan kadar MDA jaringan hati. Dosis 4 gr/100 ml dapat menurunkan kadar MDA jaringan hati namun tidak sebaik dosis $2 \mathrm{gr} / 100 \mathrm{ml}$. Hal ini terjadi karena adanya pengaruh afinitas antara molekul zat dengan reseptor. Suatu zat mampu memberikan efek maksimal jika afinitas antara molekul zat dengan reseptor bekerja dengan baik, faktor yang mempengaruhi baik atau tidaknya afinitas tersebut adalah jumlah atau konsentrasi zat bebas ditubuh. Semakin banyak konsentrasi zat bebas ditubuh maka afinistas antara molekul zat dengan reseptor bekerja semakin buruk. Sebaliknya jika konsentrasi zat bebas ditubuh sedikit dan diikuti dengan jumlah zat yang optimal dalam mengikat reseptor maka akan memberikan respon yang maksimal. ${ }^{67}$

Pada penelitian ini menyatakan bahwa terdapat perbedaan yang signifikan antara kontrol positif dengan kontrol negatif, perlakuan 1 , perlakuan 2 , dan perlakuan 3 , yaitu $\mathrm{p}=0,000$ $(\mathrm{p}<0,05)$. Perbedaan yang tidak signifikan antara kelompok perlakuan 1, perlakuan 2, dan perlakuan 3, namun menunjukkan penurunan kadar MDA jaringan hati paling baik pada kelompok perlakuan 2 .

Kawa daun gambir dapat mempengaruhi kadar MDA jaringan hati. Hal ini sejalan dengan penelitian yang dilakukan oleh Fahrudin dkk bahwa katekin berfungsi sebagai antioksidan dan hepatoprotektor sehingga dapat menurunkan kadar MDA jaringan hati. ${ }^{21}$ Efek antioksidan kawa daun gambir juga sejalan dengan penelitian yang dilakukan oleh Muhammad A'raf dkk yang menyatakan efek antioksidan kawa daun gambir dapat menurunkan kadar gula darah pada mencit. ${ }^{17}$ Penelitian juga membuktikan peran gambir sebagai antioksidan dalam bentuk isolat katekin mampu menurunkan kadar kolesterol total dan triasilgliserol pada tikus dengan dosis 20 $\mathrm{mg} / \mathrm{kgBB}$ yang diberikan selama 14 hari.22,23

\section{Kesimpulan}

Berdasarkan hasil penelitian ini, dapat disimpulkan bahwa rerata kadar MDA jaringan hati yang tidak diinduksi aloksan atau kontrol negatif adalah $8,34 \mathrm{nmol} / \mathrm{ml}$, rerata kadar MDA jaringan hati yang diinduksi aloksan tanpa diberikan intervensi lainnya atau kelompok kontrol positif adalah $12,71 \mathrm{nmol} / \mathrm{ml}$, rerata kadar MDA jaringan hati pada kelompok perlakuan 1, perlakuan 2, dan perlakuan 3 adalah 10,64 $\mathrm{nmol} / \mathrm{ml}, 8,35 \mathrm{nmol} / \mathrm{ml}, 8,46 \mathrm{nmol} / \mathrm{ml}$.

Terdapat perbedaan signifikan pengaruh pemberian kawa daun gambir terhadap kadar MDA jaringan hati pada kelompok perlakuan jika dibandingkan dengan kontrol positif. Perlakuan 2 dengan dosis kawa daun gambir 2 gr/100 ml merupakan dosis optimal untuk menurunkan kadar MDA jaringan hati dibandingkan perlakuan 1 dosis $1 \mathrm{gr} / 100 \mathrm{ml}$ dan perlakuan 3 dosis 4 gr/100 ml.

\section{Ucapan Terima Kasih}


Ucapan terima kasih peneliti sampaikan kepada seluruh pihak yang turut membantu dalam menyelesaikan penelitian ini.

\section{Daftar Pustaka}

1. Atun S. Hubungan struktur dan aktivitas antioksidan beberapa senyawa resveratrol dan turunannya. FMIPA UNY. Yogyakarta.2008.

2. Cho NH, Whiting D, Forouhi N, Guariguata L, Hambleton I, Li R, Majeed A, et al. (2015). IDF diabetes atlas.Edisi ke 7. Brussels: International Diabetes Federation. hh. 12-28.

3. World Health Organization 2017. Diabetes. diakses 14 Agustus 2018, http://www.who.int/en/newsroom/fact-sheets/detail/diabetes

4. Wells, Barbara G., J. T. DiPiro, T. L. Schwinghammer \& C. V. DiPiro. Pharmacotherapy handbook inth edition. New York: McGraw-Hill Education; 2009. p. 2-15.

5. American Diabetes Association (ADA). 2017. Standards of medical care in diabetes-2017. The Journal of Clinical and Applied Research and Education. Supplement 1. Vol. 40: 51-5135.

6. International Diabetes Federation. 2017. IDF Diabetes Atlas-8 ${ }^{\text {th }}$ Edition. http://www.diabetesatlas.org/across-the-globe.html diakses 14 Agustus 2018.

7. Handayani L, Riswati, Lestari D, Aimanah IU dan Ipa M (2013). Riset kesehatan dasar dalam angka provinsi Sumatera Barat RISKESDAS 2013. Jakarta: Lembaga Penerbitan Badan Litbangkes.

8. Tangvarasittichai, s. Oxidative stress, insulin resistance dyslipidemia and type 2 diabetes mellitus. World Journal of Diabetes; 2015. 6(3): 456-480.

9. Holt, R. I. G., C. Cockram, A. Flyvbjerg, dan Barry J. Goldstein. 2016. Textbook of Diabetes Fifth Edition. Voorhees: John Wiley \& Sons.

10. Maritim, A. C., R. A. Sanders, dan J. B. Watkins III. 2003. Diabetes, oxidative stress, and antioxidants: a review. Journal of Biochem Molecular Toxicology. 17(1): 24-38.

11. Salway, J. G. 2012. Medical Biochemistry at a Glance. Third Edition. West Sussex: John Wiley \& Sons.

12. Szendroedi, J., E. Phielix, dan M. Roden. 2012. The role of mitochondria in insulin resistance and type 2 diabetes mellitus. Nature Reviews Endocrinology. 8(2): 92- 103

13. Nurman A. Perlemakan hati non alkoholik. Universa Med.2016;26(4):205-15

14. Bedogni G, Bellentani S. Fatty liver: how frequent is it and why? Ann Hepatol Off J Mex Assoc Hepatol. 2004;3(2):63-5

15. Donne, I.D., Rossi, R., Colombo, R., Giustarini D., \& Milzani A. 2006. Biomarker of oxidative damage in human disease. Clinical Chemistry, Vol.52 (4): 601623.

16. Marra, G., P. Cotroneo, D. Pitocco, A. Manto, M. A. S. Di Leo, V. Ruotolo, S. Caputo, B. Giardina, G. Ghirlanda, dan S. A. Santini. 2002. Early increase of oxidative stress and reduced antioxidant defenses in patients with uncomplicated type 1 diabetes: a case for gender difference. Diabetes Care. 25(2): 370-375.

17. A'raaf M, Andry SP, Rizkia AW, Ansori FA, Nadiaskara SN. Uji Manfaat K-DGamb: Kawa Daun Gambir (Uncaria gambir) sebagai Antidiabetes yang Prospektif; Suatu Analisis In-vivo terhadap Mencit (Mus musculus) Diinduksi Aloksan[Program
Kreativitas Mahasiswa].Padang:Fakultas Kedokteran Universitas Andalas;2016.

18. Sabarni. Teknik pembuatan gambir (Uncaria gambir Roxb.) secara tradisional. Journal of Islamic Science and Technology. 2015;1:105-111.

19. Edward Z. 2009. The function utilization of gambier (Uncaria gambir) as the hepatoprotector. J. Ris. Kim. 2 (2):1-7.

20. Novita R, Kasim A, Anggraini T, Putra DP.Survei Proses Pembuatan Kahwa Daun di Propinsi Sumatera Barat.Padang:Fakultas Pertanian Universitas Andalas;2017.

21. Fahrudin F, Solihin Duryadi D, Kusumorini N, Ningsih S. Efektifitas Ekstrak Gambir (Uncaria gambir (Hunter) Roxb.) sebagai Hepatoprotektor pada Tikus (Rattus norvegicus L.) yang Diinduksi CCl4. J Ilmu Kefarmasian Indonesia. 2015;13(2):115-22.

22. Sari LS.Pengaruh Isolat Katekin Gambir (Uncaria gambir Roxb.) Terhadap Kadar Triasilgliserol Tikus (Rattus novergicus) [skripsi]. Padang: Fakultas Kedokteran Universitas Andalas; 2017.

23. Al Birru AB. Pengaruh Isolat Katekin Gambir (Uncaria gambir Roxb.) Terhadap Kadar Kolesterol Total Serum Tikus (Rattus novergicus) [skripsi]. Padang: Fakultas Kedokteran Universitas Andalas; 2017.

24. Ostrowska J, Luczac W, Kasacka I, Rozanski A dan Skrzydlewska E (2004). Green tea protects against ethanol-induced lipid peroxidation in rat organs. Alcohol, 32: 25-32.

25. Katzung BG. In editor: Agoes HA. Farmakologi dasar dan klinik edisi 10. Jakarta: Buku Kedokteran EGC; 2003. p. $10-13$. 